\title{
ANALISIS SIKAP, NORMA SUBYEKTIF, FAKTOR INTERNAL DAN ESKTERNAL DALAM MEMBENTUK ENTREPRENEURIAL INTENTIONS
}

\author{
Dian Triyani ${ }^{1}$, Ardiani Ika Sulistyawati ${ }^{2}$, Eddy Mulyantomo ${ }^{3}$ \\ 1,2,3 Program Studi Manajemen, Fakultas Ekonomi, Universitas Semarang \\ Jl. Soekarno Hatta, Telogosari, Semarang, Indonesia 50196
}

\begin{abstract}
This study aims to analyze the influence of attitudes, subjective norms, internal and external factors on entrepreneurial intentions. The research object of the Faculty of Economics, University of Semarang with the analysis unit of students of the Faculty of Economics, University of Semarang who is still an active status. The type of data needed in this study is primary data that comes from the answers of the respondents to the questionnaires that were distributed. The results showed that attitudes, subjective norms, internal factors and external factors had a positive and significant effect on intrapreneurial Intentions. The results of this study are only able to explain intrapreneurial Intentions only $35.8 \%$ and the remaining $64.2 \%$ are explained by other variables.
\end{abstract}

Keywords: attitudes, subjective norms, internal, external, entrepreneurial intentions

\section{Corresponding Author:}

Ardiani Ika Sulistyawati

Program Studi Manajemen, Fakultas Ekonomi, Universitas Semarang

Jl. Soekarno Hatta Telogosari, Semarang, Indonesia 50196

Email: ardiani@usm.ac.id

Research Paper

Management
(C) The Author(s) 2021

DOI: $10.36407 /$ jmsab.v4i 2.480

\section{CC)}

CC BY: This license allows reusers to distribute, remix, adapt, and build upon the material in any medium or format, so long as attribution is given to the creator. The license allows for commercial use.
Received: 27

Mei 2021

Accepted: 22

Juli 2021

Online: 27 Des 2021

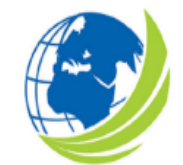

Jurnal

Manajemen

Strategi dan

Aplikasi

Bisnis,

Vol 4, No. 2,

2021,

pp. $471-483$

eISSN 2655-

237X 


\section{PENDAHULUAN}

Kewirausahaan (entrepreneurhip) merupakan masalah yang sangat penting dalam upaya peningkatan perekonomian suatu negara yang sedang berkembang. Keberadaan dan peranan dari kelompok wirausahawan turut memberikan kontribusi pada kemajuan atau kemunduran ekonomi suatu bangsa (Rachbini, 2001). Menurut Drucker (1999), seluruh proses perubahan ekonomi pada akhirnya tergantung dari orang yang menyebabkan timbulnya perubahan tersebut yakni sang "entrepreneur". Kebanyakan perusahaan yang sedang tumbuh dan yang bersifat inovatif menunjukan suatu jiwa (spirit) entrepreneur. Korporasi-korporasi berupaya untuk mendorong para manajer mereka menjadi orang-orang yang berjiwa entrepreneur, universitas-universitas sedang mengembangkan program-program entrepreneurhip, dan para entrepreneur individual menimbulkan perubahan- perubahan dramatik dalam masyarakat. Keberhasilan pembangunan yang dicapai oleh negara Jepang ternyata disponsori oleh para entrepreneur yang berjumlah $2 \%$ tingkat sedang, berwirausaha kecil sebanyak $20 \%$ dari jumlah penduduknya. Inilah kunci keberhasilan pembangunan negara Jepang (Heidjrachman, 1982). Kewirausahaan dapat pula dikatakan sebagai salah satu faktor penentu bagi kemajuan perekonomian suatu Negara. Pertumbuhan ekonomi dapat dicapai jika negara memiliki banyak wirausaha. Menurut McClelland (2009), suatu negara untuk menjadi makmur minimum memiliki jumlah wirausaha $2 \%$ dari total jumlah penduduk contohnya seperti negara Amerika Serikat memiliki 11,5 \% wirausaha, Singapura terus meningkat menjadi 7,2 \%. Dengan kata lain bahwa wirausaha adalah pelaku penting dari kegiatan ekonomi modern saat ini.

Disisi lain, pengangguran dan kemiskinan merupakan masalah klasik yang dihadapi negaranegara berkembang termasuk di Indonesia. Tingginya angka pengangguran merupakan fenomena yang terjadi di Indonesia. Banyaknya jumlah angkatan tenaga kerja yang ingin memasuki dunia pekerjaan tidak sebanding dengan lapangan pekerjaan yang tersedia. Entrepreneur di Indonesia masih bisa dapat dikatakan cukup rendah. Pada tahun 2010 lalu, dari 230 juta penduduk hanya $0.2 \%$ saja yang berwirausaha. Indonesia masih membutuhkan banyak stimulus untuk menambah jumlah pengusaha. Salah satu faktor yang mengakibatkan tingginya angka pengangguran di negara Indonesia adalah terlampau banyaknya tenaga kerja yang diarahkan ke sektor formal, sehingga ketika pekerjaan di sektor formal tidak tumbuh dan berkembang orang tidak berusaha untuk menciptakan pekerjaan sendiri di sektor swasta. Hal inilah yang mengakibatkan tingginya jumlah pengangguran dan rendahnya pertumbuhan ekonomi di Indonesia.

Salah satu alternatif untuk memecahkan masalah-masalah pengangguran dan kemiskinan di atas adalah dengan memberdayakan masyarakat melalui program kewirausahaan (entrepreneurship). Menggalakkan budaya kewirausahaan dalam masyarakat akan mampu meningkatkan perekonomian yang berpijak pada kemampuan masyarakat untuk dapat melakukan usaha yang produktif. Pengaruh pendidikan kewirausahaan selama ini telah dipertimbangkan sebagai salah satu faktor penting untuk menumbuhkan dan mengembangkan hasrat, jiwa dan perilaku berwirausaha di kalangan generasi muda (Kourilsky \& Walstad, 1998). Terkait dengan pengaruh pendidikan kewirausahaan tersebut, diperlukan adanya pemahaman tentang bagaimana mengembangkan dan mendorong lahirnya wirausahawirausaha muda yang potensial sementara mereka berada di bangku pendidikan. Beberapa penelitian sebelumnya menyebutkan bahwa keinginan berwirausaha para mahasiswa merupakan sumber bagi lahirnya wirausaha-wirausaha masa depan (Kourilsky \& Walstad, 1998). Sikap, perilaku dan pengetahuan mereka tentang kewirausahaan akan membentuk kecenderungan mereka untuk membuka usaha-usaha baru di masa mendatang.

Menurut Theory of Planned Behavior/TPB (Ajzen, 1991 dalam Dharmmesta, 1998), sebuah perilaku dengan keterlibatan tinggi membutuhkan keyakinan dan evaluasi untuk menumbuhkan sikap dan norma subyektif dengan intensi sebagai mediator pengaruh berbagai faktor-faktor motivasional yang berdampak pada suatu perilaku. Keputusan berwirausaha merupakan perilaku dengan keterlibatan tinggi karena di dalam proses pengambilan keputusan, tentunya akan melibatkan berbagai faktor yang berasal dari dalam diri sendiri (internal factors), seperti kepribadian, persepsi, sikap dan motivasi. Selain itu juga 
diperlukan faktor yang berasal dari luar (external factors) yaitu faktor keluarga, tetangga, teman dan juga faktor-faktor lain yang bersifat subyektif.

Beberapa penelitian telah dilakukan mengenai variabel-variabel yang mempengaruhi intensi berwirausaha. Tjahjono \& Ardi (2008) dan Wijaya (2008) menemukan bahwa sikap dan norma subyektif berpengaruh terhadap intensi berwirausaha.. Azjen \& Fishbein (1980) dalam theory of planned behavior membuktikan bahwa intensi juga dipengaruhi oleh sikap dan norma subyektif.

Mahasiswa Fakultas Ekonomi Universitas Semarang terbagi menjadi tiga program studi yang menekuni ilmu manajemen dan ilmu akuntansi baik dalam bentuk teori maupun praktek ilmu ekonomi khususnya kewirausahaan yang masuk di dalam kurikulum setiap program studi. Dengan memberikan ilmu-ilmu dasar mengenai kewirausahaan diharapkan akan menumbuhkan jiwa wirausaha dan lebih jauh lagi dapat menjadi wirausaha yang unggul agar tidak menggantungkan kerja pada orang lain, sehingga diperlukan keberanian untuk membuka usaha sendiri atau berwirausaha.

Mata kuliah kewirausahaan merupakan mata kuliah yang wajib diikuti oleh mahasiswa Fakultas Ekonomi Universitas Semarang baik pada Program Studi S1 Manajemen, D3 Manajemen Perusahaan maupun S1 Akuntansi. Salah satu metode pembelajaran yang digunakan adalah mahasiswa didorong untuk melakukan kegiatan wirausaha, dengan membuat dan memasarkan produk yang dihasilkannya melalui kegiatan Wirausaha Expo yang secara rutin dilaksanakan. Hal ini dilakukan untuk mendorong kreativitas mahasiswa dan mengetahui seberapa jauh kemampuan mahasiswa dalam menjadi wirausahawan. Bagi sebagian mahasiswa, kegiatan ini dianggap sebagai salah satu media latihan bagi minat berwirausaha, namun bagi sebagian yang lain, aktivitas ini hanya tuntutan untuk mendapat nilai semata.

Dengan demikian, perlu dilakukan penelitian yang bermaksud untuk mengetahui atau mengeksplorasi faktor-faktor yang berpengaruh pada minat berwirausaha pada mahasiswa, sehingga pada program perkuliahan dapat ditekankan secara optimal. Penelitian ini diharapkan akan berimplikasi pada pengembangan kewirausahaan di program studi yang bersangkutan, sehingga bisa menanamkan nilai-nilai yang diperlukan untuk menunjang pengembangan minat berwirausaha mahasiswa. Tujuan penelitian untuk menguji dan memberikan bukti secara empiris pengaruh sikap, norma subyektif, faktor internal dan faktor eksternal di dalam meningkatkan entrepreneurial intentions.

\section{KAJIAN PUSTAKA}

Perilaku Kewirausahaan

Jogiyanto (2008), teknologi informasi diterapkan agar manusia berinteraksi menggunakan sistem teknologi informasi tetapi masih banyak bahwa sistem teknologi informasi gagal yang diterapkan karena manusia menolak atau tidak mau menggunakannya dengan banyak alasan. Menolak menggunakan sistem adalah suatu perilaku (behavior). Teori keperilakuan merupakan bagian dari ilmu psikologi karena di aliran psikologi mempelajari perilaku yang dapat di observasi atau diukur karena perilaku dapat dipelajari dan dijelaskan. Psikologi adalah perilaku dan proses-proses mental yang mencoba mendeskripsikan, menjelaskan, memprediksi, dan mengendalikan aspek-aspek dari perasaan perilaku adalah tindakan yang dilakukan oleh seseorang dan kegiatan.

Jogiyanto (2008), perilaku (behavior) adalah tindakan-tindakan (actions) atau reaksi-reaksi (reactions) dari suatu obyek. Perilaku dapat berupa sadar (conscius) atau tidak sadar (unconscious), terang-terang (overt) atau diam-diam (covert), sukarela (voluntary) atau tidaksukarela (involuntary). Sistem informasi keperilakuan membahas aspek perilaku (behavior) dari individual-individual dalam hubungannya dengan sistem informasi. Sistem informasi keperilakuan menjelaskan tindakan-tindakan pemakai sistem informasi tersebut.

Hisrich et al (2008), kewirausahaan merupakan proses menciptakan sesuatu yang baru dan mengambil segala risiko dan imbalannya sedangkan wirausaha adalah seorang innovator yaitu seseorang yang mengembangkan sesuatu yang unik dan berbeda. Siagian (2016) mendefinisikan kewirausahaan adalah semangat, perilaku, dan kemampuan untuk memberikan tanggapan yang positif terhadap peluang memperoleh keuntungan untuk diri sendiri dan atau pelayanan yang lebih baik pada pelanggan/masyarakat; dengan selalu 
berusaha mencari dan melayani langganan lebih banyak dan lebih baik, serta menciptakan dan menyediakan produk yang lebih bermanfaat dan menerapkan cara kerja yang lebih efisien, melalui keberanian mengambil resiko, kreativitas dan inovasi serta kemampuan manajemen. Meredith et. al (2000) mengatakan bahwa para wirausaha adalah orang-orang yang mempunyai kemampuan melihat dan menilai kesempatan bisnis, mengumpulkan sumber-sumber daya yang dibutuhkan guna mengambil keuntungan daripadanya dan mengambil tindakan yang tepat guna memastikan sukses. Kesuksesan dari seorang wirausaha selalu tidak terpisahkan dari kreativitas dan inovasi. Inovasi tercipta karena adanya daya kreativitas yang tinggi. Kreativitas adalah kemampuan untuk membawa sesuatu yang baru ke dalam kehidupan yang merupakan sumber yang penting dari kekuatan persaingan, karena lingkungan cepat sekali berubah.

Sikap

Sikap dikatakan sebagai suatu respons evaluatif. Respon hanya akan timbul apabila individu dihadap-kan pada suatu stimulus yang menghendaki adanya reaksi individual. Respon evaluatif berarti bahwa bentuk reaksi yang dinyatakan sebagai sikap itu timbulnya didasari oleh proses evaluasi dalam diri individu yang memberi kesimpulan terhadap stimulus dalam bentuk nilai baik-buruk, positif-negatif, menyenangkan-tidak menyenangkan, yang kemudian mengkristal sebagai potensi reaksi terhadap objek sikap. Jadi sikap memberikan evaluasi terhadap objek (Shaw \& Constanzo, 1970). Sikap berwirausaha mengacu pada respons individu terhadap risiko dalam berbisnis dan berani menghadapi rintangan dalam dunia usaha. Sikap individu yang mampu mentoleransi risiko (Zhao et al., 2005) dan berani menghadapi rintangan dalam dunia usaha (Wijaya, 2007) memiliki intensi untuk berwirausaha.

Norma Subyektif

Hogg \& Vaughan (2005), penjelasan bahwa norma subyektif adalah produk dari persepsi individu tentang beliefs yang dimiliki orang lain. Norma subjektif diukur dengan skala subjective norm (Ramayah \& Harun, 2005) dengan indikator keyakinan peran keluarga dalam memulai usaha, keyakinan dukungan teman dalam usaha, keyakinan dukungan dari dosen, keyakinan dukungan dari pengusaha-pengusaha yang sukses, dan keyakinan dukungan dalam usaha dari orang yang dianggap penting.

Motivasi

Motivasi merupakan hal yang melatar belakangi individu berbuat untuk mencapai tujuan tertentu. Seseorang yang dengan sengaja mengikatkan diri menjadi bagian dari organisasi mempunyai latar belakang yang berbeda-beda, salah satunya adalah agar mereka dapat berinteraksi dengan manusia lainnya dan agar kebutuhan hidupnya dapat terpenuhi. Adapun jenis motivasi menurut Davis \& Strom (1996) adalah prestasi, afiliasi, kompetensi, dan kekuasaan. Menurut Law \& Hung (2009), upaya memahami karakteristik wirausaha dengan menggunakan aspek kepribadian menghasilkan karakteristik sebagai berikut: wirausaha cenderung pengambil risiko, berorientasi mencapai hasil, komitmen, toleransi terhadap ketidakpastian dan mempunyai visi (Kurnianto \& Putra, 2012)

Faktor Internal dan Faktor Eksternal

Entrepreneurial process akan terjadi dan diperkuat oleh keberadaan kondisi atau faktor lingkungan. Faktor ini terdiri dari lingkungan fisik, lingkungan ekonomi, lingkungan organisasi dan kelembagaan serta lingkungan individu. Hasil penelitian Hisrich et al (2008) menemukan bahwa 50 persen dari 408 entrepreneur wanita merupakan anak sulung. Argumentasi yang diajukan adalah anak sulung atau anak tunggal akan mendapat perhatian yang lebih dari orangtua dalam pengembangan kepercayaan diri dan modal sosialnya sehingga mempermudah tumbuhnya kewirausahaan. Dalam hal latar belakang pekerjaan orang tua, banyak peneliti yang mengatakan bahwa pekerjaan orang tua yang entrepreneur, 50 persen lebih akan menghasilkan pula seorang anak yang entrepreneur. Kemudian hubungan dengan orang tua secara umum, apakah pengusaha atau bukan, sangat besar pengaruhnya terhadap perkembangan kewirausahaan seseorang karena orang tua akan mendorong anaknya untuk menjadi independen, maju dan bertanggungjawab (Hisrich et al, 2008). Orang tua yang bekerja secara mandiri atau wiraswasta akan berpengaruh terhadap keputusan anaknya apakah bekerja wiraswasta atau bekerja sebagai pegawai yang diupah. Pengalaman masa kanak-kanak yang didapat dari orangtuanya akan sangat menentukan sikap 
dia dalam bekerja. Jika orangtuanya berwiraswasta, pilihan pertama anaknya ketika harus bekerja akan jatuh pada pekerjaan berwiraswasta (self employment).

Hipotesis

H1 : Sikap berpengaruh signifikan terhadap entrepreunerial intentions.

$\mathrm{H} 2$ : Norma subyektif berpengaruh terhadap entrepreunerial intentions

H3 : Faktor internal berpengaruh terhadap entrepreunerial intentions

$\mathrm{H} 4$ : Faktor eksternal berpengaruh terhadap entrepreunerial intentions

\section{METODE}

Jenis data yang digunakan dalam penelitian ini adalah data primer, yaitu data yang didapatkan secara langsung dari sumbernya. Adapun sumber data dalam penelitian ini adalah jawaban para responden, yaitu para mahasiswa di Fakultas Ekonomi Universitas Semarang melalui jawaban pada kuesioner dan hasil wawancara. Populasi dalam penelitian ini adalah semua mahasiswa Fakultas Ekonomi Universitas Semarang yang masih berstatus aktif, dari tiga program studi yaitu S1 Manajemen, D3 Manajemen Perusahaan dan S1 Akuntansi. Teknik pengambilan sampel menggunakan Purposive Sampling, dengan beberapa kriteria sebagai berikut : 1) Mahasiswa aktif Fakultas Ekonomi Universitas Semarang. 2) Mahasiswa Fakultas Ekonomi Universitas Semarang yang telah mengikuti mata kuliah Kewirausahaan. Hal ini didasarkan pada pertimbangan bahwa mahasiswa tersebut telah memilki suatu pandangan terhadap definisi dan kegiatan perekonomian, khususnya kewirausahaan. Instrumen disebut valid jika semua instrumen dari daftar pertanyaan yang diujikan sudah memenuhi kriteria uji validitas dimana $r$ hitung $>r$ tabel dan variabel disebut reliabel bila nilai cronbach alpha di atas 0,60. Suatu data berdistribusi normal atau tidak normal maka menggunakan uji Kolmogorov Smirnov yaitu dengan meilihat angka signifikan lebih besar dari 0,05 disebut distribusi data normal. Untuk menguji apakah dalam model regresi ditemukan adanya korelasi antar variabel bebas maka dilakukan uji multikolonieritas, dengan ketentuan jika VIF $<10$ maka tidak terjadi multikolonieritas. Sebuah model regresi terjadi ketidaksamaan varians dari residual dari satu pengamatan satu ke pengamatan yang lain maka digunakan uji Glejser, yaitu jika variabel independen signifikan $>0,05$ disebut tidak terjadi heterokedastisitas.

Persamaan regresi : $\quad \mathrm{Y}=\mathrm{B} 1 . \mathrm{X} 1+\mathrm{B} 2 . \mathrm{X} 2+\mathrm{B} 3 . \mathrm{X} 3+\mathrm{B} 4 . \mathrm{X} 4+\mathrm{e}$

Dimana :

$$
\begin{array}{ll}
\mathrm{Y} & =\text { entrepreunerial intentions } \\
\mathrm{X} 1 & =\text { sikap } \\
\mathrm{X} 2 & =\text { norma subyektif } \\
\mathrm{X} 3 & =\text { faktor internal } \\
\mathrm{X} 4 & \text { = faktor eksternal } \\
\mathrm{B} & =\text { koefisien regresi }
\end{array}
$$

Sebelum dilakukannya uji hipotesis, terlebih dahulu akan dilakukan analisis deksriptif berdasarkan jawaban responden, uji validitas, uji reliabilitas, uji normalitas dan kemudian uji t,

\begin{tabular}{|c|c|c|c|c|c|c|c|}
\hline \multirow[t]{3}{*}{ No } & \multirow[t]{3}{*}{ Pernyataan } & \multicolumn{5}{|c|}{ Persentase Jawaban Responden } & \multirow{3}{*}{$\begin{array}{l}\text { Rerata } \\
(\text { Mean) }\end{array}$} \\
\hline & & 1 & 2 & 3 & 4 & 5 & \\
\hline & & STS & TS & $\mathrm{N}$ & $\mathrm{S}$ & SS & \\
\hline 1 & Tertarik dengan peluang usaha & 0,4 & 0,0 & 4,6 & 35,3 & 59,8 & 4,54 \\
\hline 2 & Berfikir kreatif dan inovatif & 0,0 & 0,4 & 14,5 & 49,8 & 35,3 & 4,20 \\
\hline 3 & Pandangan positif terhadap kegagalan & 0,8 & 3,7 & 29,9 & 35,7 & 29,9 & 3,90 \\
\hline 4 & Memiliki jiwa kepemimpinan dan tanggung jawab & 0,0 & 2,5 & 18,3 & 52,7 & 26,6 & 4,03 \\
\hline 5 & Suka menghadapi risiko dan tantangan & 0,0 & 2,5 & 19,5 & 53,1 & 24,9 & 4,00 \\
\hline
\end{tabular}
uji F serta koefisien determinasi.

\section{HASIL DAN PEMBAHASAN}

Tanggapan Responden Terhadap Sikap

\section{Tabel 1.}

Deskripsi Frekuensi Jawaban Responden pada Sikap

Sumber: Data yang diolah, 2021 
Pada Tabel 1 diperoleh suatu gambaran bahwa nilai yang paling banyak dipilih oleh responden 4 atau setuju. Hasil penelitian ini membuktikan bahwa sikap mahasiswa tergolong tinggi dan tinggi. Sikap tersebut dapat diartikan bahwa mahasiswa sangat tertarik dengan peluang usaha, mahasiswa mampu berpikir kreatif dan inovatif, mahasiswa memandang positif terhadap kegagalan, mahasiswa memiliki jiwa kepemimpinan dan tanggung jawab serta mahasiswa suka menghadapi risiko dan tantangan. Diperoleh rata-rata paling tinggi adalah ketertarikan terhadap peluang usaha, hal tersebut menunjukkan bahwa tingginya afektif mahasiswa disebabkan faktor ketertarikan terhadap peluang usaha.

\section{Tanggapan Responden Terhadap Norma Subyektif}

\section{Tabel 2.}

Deskripsi Persentase Jawaban Responden pada Norma Subyektif

\begin{tabular}{llllllll}
\hline \multirow{2}{*}{ No } & Pernyataan & \multicolumn{3}{l}{ Persentase Jawaban Responden } & Rerata \\
\cline { 3 - 6 } & & 1 & 2 & 3 & 4 & 5 & \\
\cline { 3 - 6 } & & STS & TS & N & S & SS & \\
\hline 1 & Keyakinan dukungan dari peran keluarga & 0,0 & 0,0 & 7,1 & 41,1 & 51,9 & 4,45 \\
2 & Keyakinan dukungan teman & 0,0 & 0,0 & 14,1 & 51,9 & 34,0 & 4,20 \\
3 & Keyakinan dukungan dari dosen & 0,0 & 0,0 & 16,6 & 51,0 & 32,4 & 4,16 \\
4 & Keyakinan dukungan dari pengusaha sukses & 0,0 & 2,1 & 21,2 & 46,9 & 29,9 & 4,05 \\
5 & $\begin{array}{l}\text { Keyakinan dukungan dari orang yang dianggap } \\
\text { penting }\end{array}$ & 0,0 & 0,0 & 8,7 & 42,7 & 48,5 & 4,40 \\
\end{tabular}

Sumber: Data yang diolah, 2021

Pada Tabel 2 diperoleh suatu gambaran bahwa nilai yang paling banyak dipilih oleh responden adalah 4 atau setuju. Hasil penelitian ini membuktikan bahwa tanggapan mahasiswa tentang norma subyektif mahasiswa adalah tinggi. Norma subyektif mahasiswa pada penelitian ini dapat diartikan bahwa mahasiswa mempunyai keyakinan sangat tinggi mendapat dukungan dari keluarga. Mahasiswa yakin mendapat dukungan teman. Mahasiswa yakin mendapat dukungan dosen. Mahasiswa yakin mendapat dukungan dari pengusaha sukses dan mahasiswa yakin mendapat dukungan dari orang yang paling penting dalam hidupnya. Keyakinan dukungan paling tinggi diperoleh dari keluarga dengan nilai rata-rata 4,45 .

\section{Tanggapan Responden Terhadap Faktor Internal}

\section{Tabel 3.}

Deskripsi Persentase Jawaban Responden pada Norma Subyektif

\begin{tabular}{lllllllll}
\hline No & Pernyataan & \multicolumn{5}{c}{ Persentase Jawaban Responden } & Rerata \\
(Mean)
\end{tabular}

Sumber: Data yang diolah, 2021

Pada Tabel 3 diperoleh suatu gambaran bahwa nilai yang paling banyak dipilih oleh responden adalah 4 atau setuju. Hasil penelitian ini membuktikan bahwa pernyataan mahasiswa tentang faktor internal tinggi. Jadi mahasiswa mempunyai motivasi tinggi baik motivasi prestasi, motivasi afiliasi, motivasi kompetensi, motivasi kekuasaan. Mahasiswa berani mengambil resiko, mempunyai orientasi hasil tinggi, komitmen tinggi, mampu mentoleransi ketidakpastian usaha dan mempunyai visi yang baik. 


\section{Tanggapan Responden Terhadap Faktor Eksternal}

\section{Tabel 4.}

Deskripsi Persentase Jawaban Responden pada Faktor Eksternal

\begin{tabular}{lllllllll}
\hline \multirow{2}{*}{ No } & Pernyataan & \multicolumn{3}{c}{ Persentase Jawaban Responden } & Rerata \\
\cline { 3 - 6 } & & 1 & 2 & 3 & 4 & 5 & & (Mean) \\
\cline { 3 - 6 } & & STS & TS & N & S & SS & \\
\hline 1 & Pekerjaan orang tua, dukungan orang tua & 0,0 & 0,0 & 5,4 & 40,7 & 53,9 & 4,49 \\
2 & Faktor budaya dan pergaulan & 0,0 & 0,4 & 17,0 & 48,5 & 34,0 & 4,16 \\
\hline
\end{tabular}

Sumber: Data yang diolah, 2021

Pada Tabel 4 diperoleh suatu gambaran bahwa nilai yang paling banyak dipilih oleh responden adalah 4. Hasil penelitian ini membuktikan bahwa pernyataan mahasiswa tentang faktor eksternal dikategorikan tinggi. Hal tersebut memberi arti bahwa pekerjaan orang tua sangat mendukung mahasiswa niat berwirausaha dan juga faktor budaya dan pergaulan juga sangat mendukung mahasiswa berintensi wirausaha.

\section{Tanggapan Responden Terhadap Entrepreunerial Intentions}

\section{Tabel 5.}

Deskripsi Persentase Jawaban Responden pada Entrepreunerial Intentions

\begin{tabular}{|c|c|c|c|c|c|c|c|}
\hline \multirow[t]{3}{*}{ No } & \multirow[t]{3}{*}{ Pernyataan } & \multicolumn{5}{|c|}{ Persentase Jawaban Responden } & \multirow{3}{*}{$\begin{array}{l}\text { Rerata } \\
\text { (Mean) }\end{array}$} \\
\hline & & 1 & 2 & 3 & 4 & 5 & \\
\hline & & STS & TS & $\mathrm{N}$ & $\mathrm{S}$ & SS & \\
\hline 1 & $\begin{array}{l}\text { Memilih berwirausaha daripada bekerja pada } \\
\text { orang lain }\end{array}$ & 0,0 & 0,8 & 28,2 & 32,8 & 38,2 & 4,08 \\
\hline 2 & Memilih berkarir sebagai wirausahawan & 0,0 & 0,4 & 22,8 & 39,0 & 37,8 & 4,14 \\
\hline 3 & Melakukan perencanaan untuk memulai usaha & 0,0 & 0,0 & 9,1 & 41,5 & 49,4 & 4,40 \\
\hline 4 & $\begin{array}{l}\text { Meningkatkan status sosial dan harga diri sebagai } \\
\text { wirausaha }\end{array}$ & 0,4 & 4,1 & 23,7 & 38,2 & 33,6 & 4,00 \\
\hline 5 & Mendapatkan pendapatan yang lebih baik & 0,0 & 0,8 & 20,7 & 45,2 & 33,2 & 4,11 \\
\hline
\end{tabular}

Sumber: Data yang diolah, 2021

Pada Tabel 5 diperoleh suatu gambaran bahwa nilai yang paling banyak dipilih oleh responden adalah 4 atau setuju. Hasil penelitian ini membuktikan bahwa Entrepreunerial Intentions mahasiswa dikategorikan tinggi, hal tersebut memberi arti bahwa mahasiswa memilih berwirausaha daripada bekerja pada orang lain, mahasiswa memilih berkarir sebagai wirausahawan, mahasiswa melakukan perencanaan untuk memulai usaha, menurut mahasiswa berwirausaha merupakan usaha untuk meningkatkan status sosial dan harga diri, menurut mahasiswa dengan berwirausaha mendapatkan pendapatan yang lebih baik.

Tabel 6.

Hasil Uji Validitas

\begin{tabular}{llll}
\hline Item & r hitung & r tabel $(\mathrm{df}-2)$ & Keterangan \\
\hline X1.1 & 0,350 & 0,1062 & Valid \\
X1.2 & 0,598 & 0,1062 & Valid \\
X1.3 & 0,633 & 0,1062 & Valid \\
X1.4 & 0,575 & 0,1062 & Valid \\
X1.5 & 0,646 & 0,1062 & Valid \\
X2.1 & 0,512 & 0,1062 & Valid \\
X2.2 & 0,632 & 0,1062 & Valid \\
X2.3 & 0,567 & 0,1062 & Valid \\
X2.4 & 0,501 & 0,1062 & Valid \\
X2.5 & 0,555 & 0,1062 & Valid \\
X3.1 & 0,386 & 0,1062 & Valid \\
X3.2 & 0,386 & 0,1062 & Valid \\
X4.1 & 0,520 & 0,1062 & Valid \\
X4.2 & 0,520 & 0,1062 & Valid \\
X2.5 & 0,555 & 0,1062 & Valid \\
\hline
\end{tabular}




\begin{tabular}{llll}
\hline X2.1 & 0,512 & 0,1062 & Valid \\
X2.2 & 0,632 & 0,1062 & Valid \\
Y1.1 & 0,635 & 0,1062 & Valid \\
Y1.2 & 0,668 & 0,1062 & Valid \\
Y1.3 & 0,357 & 0,1062 & Valid \\
Y1.4 & 0,587 & 0,1062 & Valid \\
Y1.5 & 0,672 & 0,1062 & Valid \\
\hline
\end{tabular}

Sumber : Data primer yang diolah, 2021

Tabel 6 diperoleh semua nilai $r$ hitung pada butir-butir variabelnya lebih besar dari $r$ tabel dan bernilai positif. Oleh karena itu semua item dinyatakan valid dan dapat digunakan untuk penelitian.

Tabel 7.

Hasil Uji Reliabilitas

\begin{tabular}{llll}
\hline Variabel & $\begin{array}{l}\text { Cronbach } \\
\text { Alpha }\end{array}$ & $\begin{array}{l}\text { Angka } \\
\text { Standar } \\
\text { Reliabel }\end{array}$ & Keterangan \\
\hline Sikap $\left(\mathrm{X}_{1}\right)$ & 0,782 & 0,60 & Reliabel \\
Norma Subyektif $\left(\mathrm{X}_{2}\right)$ & 0,777 & 0,60 & Reliabel \\
Faktor Internal $\left(\mathrm{X}_{3}\right)$ & 0,556 & 0,60 & Kurang Reliabel \\
Faktor Eksternal $\left(\mathrm{X}_{4}\right)$ & 0,678 & 0,60 & Reliabel \\
Interpreneurial Intentions $(\mathrm{Y})$ & 0,799 & 0,60 & Reliabel \\
\hline
\end{tabular}

Sumber : Data primer yang diolah, 2021

Tabel 7 menunjukkan konsistensi internal dari butir-butir pertanyaan yang berkaitan dengan variabel Sikap $\left(\mathrm{X}_{1}\right)$ dalam penelitian ini ditunjukkan dengan koefisien Alpha sebesar 0,782. Norma Subyektif $\left(\mathrm{X}_{2}\right)$ mempunyai koefisien alpha sebesar 0,777. Faktor Internal $\left(\mathrm{X}_{3}\right)$ mempunyai koefisien alpha sebesar 0,556 kurang reliabel, namun menurut Santoso (2000), nilai $\mathrm{r}$ alpha di atas $\mathrm{r}$ table masih dikatakan reliabel. Interpreneurial Intentions ditunjukkan dengan koefisien alpha sebesar 0,799 . Faktor eksternal $\left(\mathrm{X}_{4}\right)$ mempunyai koefisien alpha sebesar 0,678 .

Tabel 8.

Hasil Uji Normalitas

\begin{tabular}{llll}
\hline Model/Persamaan & Nilai Z hitung & Nilai Z table & Kesimpulan \\
\hline 1 & 0,072 & $\pm 1,96$ & Normal \\
\hline
\end{tabular}

Sumber : Data primer yang diolah, 2021

Tabel 8 menunjukkan nilai Z hitung lebih besar dari -1,96 dan lebih kecil dari 1,96. Hasil tersebut menunjukkan bahwa data pada penelitian ini berdisribusi normal.

Tabel 9.

Hasil Uji Multikolenieritas

\begin{tabular}{lll}
\hline Persamaan/Model & \multicolumn{2}{l}{ Collinearity Statistics } \\
\cline { 2 - 3 } & Tolerance & VIF \\
\hline Sikap (X1) & 0,539 & 1,856 \\
Norma Subyektif (X2) & 0,418 & 2,395 \\
Faktor Internal (X3) & 0,561 & 1,784 \\
Faktor Eksternal (X4) & 0,444 & 2,252 \\
\hline
\end{tabular}

Sumber : Data primer yang diolah, 2021

Tabel 9 menunjukkan bahwa bahwa pada persamaan regresi didapatkan nilai tolerance paling kecil sebesar 0,418, masih lebih besar dari 0,1 dan nilai VIF terbesar 2,395 masih lebih kecil 
dari angka 10. Jadi variabel-variabel bebas yang digunakan dalam model regresi tidak menunjukkan adanya gejala multikolonieritas.

Scatterplot

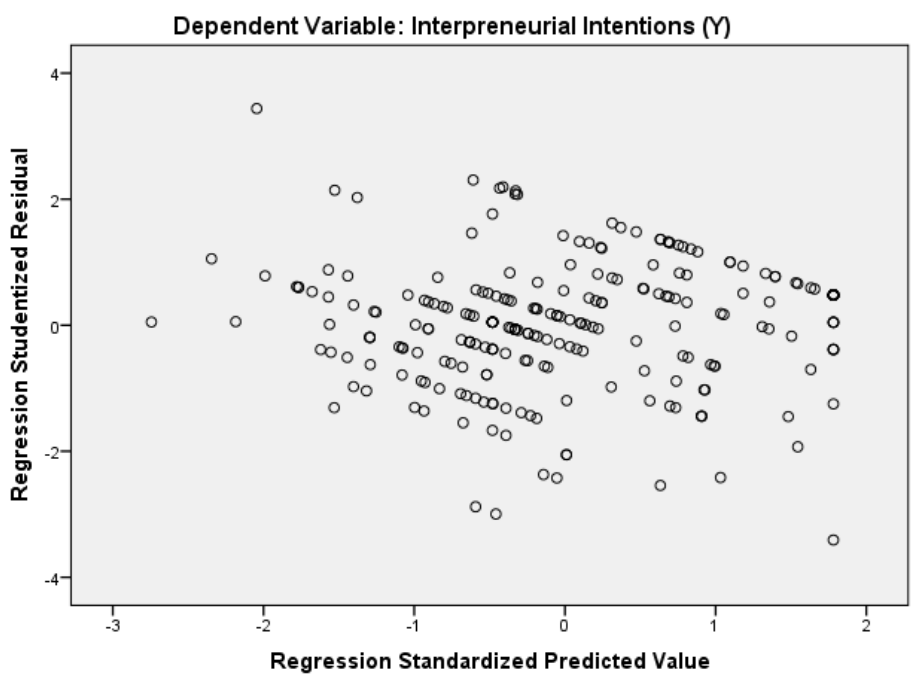

Gambar 1. Grafik Scatterplot

Berdasarkan grafik scatterplot persamaan menunjukkan titik-titiknya menyebar dibawah angka nol dan di atas angka nol, sehingga dapat dikatakan terbebas dari masalah heteroskedastisitas.

Tabel 10.

Hasil Uji Regresi Linier Berganda

\begin{tabular}{|c|c|c|c|c|}
\hline \multicolumn{2}{|c|}{ Model 1} & $\frac{\text { Standardized Coefficients }}{\text { Beta }}$ & $\mathrm{t}$ & Sig. \\
\hline 1 & (Constant) & & 2,652 & 0,009 \\
\hline & Sikap (X1) & 0,248 & 3,513 & 0,001 \\
\hline & Norma Subyektif (X2) & 0,354 & 4,426 & 0,000 \\
\hline & Faktor Internal (X3) & 0,086 & 1,243 & 0,215 \\
\hline & Faktor Eksternal (X4) & 0,029 & 0,370 & 0,712 \\
\hline
\end{tabular}

Sumber : Data primer yang, 2021

Hasil penelitian dapat dilihat dalam persamaan berikut:

$\mathrm{Y}=0,248 \mathrm{X} 1+0,354 \mathrm{X} 2+0,086 \mathrm{X} 3+0,029 \mathrm{X} 4+\mathrm{e}$

Keterangan:

$\begin{array}{ll}\mathrm{Y} & =\text { Interpreneurial Intentions } \\ \mathrm{X} 1 & =\text { Sikap } \\ \mathrm{X} 2 & =\text { Norma Subyektif } \\ \mathrm{X} 3 & =\text { Faktor Internal } \\ \mathrm{X} 4 & =\text { Faktor Eksternal }\end{array}$

Hasil persamaan regersi membuktikan adanya pengaruh positif dari variabel Afektif, Norma Subyektif, Faktor Internal dan Faktor Eksternal terhadap Interpreneurial Intentions.

Tabel 11.

Uji Ketepatan Model

\begin{tabular}{llll}
\hline Model & F hitung & Nilai Sig & Kesimpulan \\
\hline 1 & 34,411 & 0,000 & Ada pengaruh simultan/model fit \\
\hline
\end{tabular}

Sumber : Data primer yang diolah, 2021 
Dari hasil uji F, menunjukkan bahwa nilai signifikansi sebesar 0,000 lebih kecil dari tingkat $\alpha$ $=0,05$. Hasil ini mengindikasi bahwa variabel bebas penelitian ini layak digunakan sebagai variabel prediktor Entrepreunerial Intentions.

Tabel 12.

Hasil Uji Koefisien Determinasi

\begin{tabular}{lllll}
\hline Model & $\mathrm{R}$ & R Square & Adjusted R Square & Std. Error of the Estimate \\
\hline 1 & 0,607 & 0,368 & 0,358 & 2,337 \\
\hline
\end{tabular}

Sumber : Data primer yang diolah,2021

Tabel 12 menunjukkan bahwa nilai koefisien determinasi sebesar 0,358 atau 35,8\%. Koefisien sebesar 35,8\% memberi arti bahwa Interpreneurial Intentions dapat dijelaskan oleh variabel Sikap, Norma Subyektif, Internal dan Eksternal sebesar 35,8\%, sedangkan sisanya sebesar $64,2 \%$ dijelaskan faktor-faktor lain yang tidak diteliti pada penelitian ini.

\section{Pembahasan}

Pada Tabel 10 menunjukkan bahwa sikap memiliki nilai t hitung positif dan signifikan sebesar 0,001 lebih kecil dari 0,05 dapat disimpulkan bahwa sikap berpengaruh positif dan signifikan terhadap Interpreneurial Intentions. Semakin tinggi sikap maka semakin baik Interpreneurial Intentions, Hal ini sesuai dengan tingginya nilai skor yang mereka berikan untuk indikator tertarik dengan peluang usaha. Hasil penelitian ini sejalan dengan Sumadi \& Sulistyawati (2017). Wijaya (2008) menemukan bahwa sikap berpengaruh terhadap intensi berwirausaha. Namun, hasil penelitian ini tidak sejalan dengan penelitian Mihartinah \& Corynata (2018) yang justru menyatakan bahwa sikap trhdap peerilaku tidak berpengaruh terhadap niat berperilaku .

Pada Tabel 10 menunjukkan bahwa Norma Subyektif memiliki nilai t hitung positif dan signifikan sebesar 0,000 lebih kecil dari 0,05 dapat disimpulkan bahwa Norma Subyektif berpengaruh positif dan signifikan terhadap Interpreneurial Intentions. Semakin tinggi Norma Subyektif maka semakin baik Interpreneurial Intention, sebaliknya semakin kurang Norma Subyektif auditor maka semakin rendah Interpreneurial Intentions. Hal ini sesuai dengan tingginya nilai skor yang mereka berikan untuk indikator motivasi prestasi, motivasi afiliasi, motivasi kompetensi, motivasi kekuasaan. Hasil penelitianm ini sesuai dengan penelitian sebelumnya, yaitu : Tjahjono \& Ardi (2007), Wijaya (2008), Andika \& Madjid (2012), Azjen \& Fishbein (1988) dalam theory of planned behavior membuktikan bahwa intensi dipengaruhi oleh norma subyektif.

Pada Tabel 10 menunjukkan bahwa faktor internal memiliki nilai t hitung positif dan tidak signifikan sebesar 0,215 lebih besar dari 0,05 dapat disimpulkan bahwa faktor internal berpengaruh positif dan tidak signifikan terhadap Interpreneurial Intentions. Jadi faktor internal berpengaruh kecil terhadap Interpreneurial Intentions. Hal ini sesuai dengan tingginya nilai skor yang mereka berikan untuk indikator melakukan perencanaan untuk memulai usaha. Faktor-faktor dari dalam individu yang mempengaruhi individu dan merupakan faktor yang dapat dikendalikan yang di tetapkan. Seorang wirausaha yang memiliki keinginan Melakukan perencanaan untuk memulai usaha akan mencetak wirusahawan yang unggul dan mencapai kesuksesan dalam berwirausaha. Hal ini merupakan salah satu sifat faktor pendorong yang mempengaruhi Interpreneurial Intentions. Temuan penelitian ini memberikan bukti empirik bahwa prediktor utama dari niat adalah faktor internal untuk melakukan niat tersebut serta mendukung temuan dari penelitian-penelitian terdahulu dalam berbagai konteks (Afifah et al, 2016; Ananta \& Oktafani, 2019), Yaspita, 2018, Nagel \& Suhartatik, 2018, Widhiandono,2014), Ifham \& Helmi, 2002, Hadiyati, 2011. Namun hasil penelitian ini justru berlawanan dengan hasil penelitian Tisa \& Anggadwita (2018) yang menyatakan bahwa faktor internal tidak mempengaruhi niat seseorang berwirausasha 
Pada Tabel 10 menunjukkan bahwa faktor eksternal memiliki nilai thitung positif dan tidak signifikan sebesar 0,712 lebih besar dari 0,05 dapat disimpulkan bahwa faktor eksternal berpengaruh positif dan kecil terhadap Interpreneurial Intentions. Hal ini sesuai dengan tingginya nilai skor yang mereka berikan untuk indikator pekerjaan orang tua, dukungan orang tua. Faktor eksterenal ini terjadi karena adanya dorongan rasa dari luar yang mana dapat mempengaruhi individu tersebut untuk memiliki rasa minat terhadap wirausaha. Keluarga merupakan sosialisasi primer yang menjadi pembentuk kepribadian seseorang termasuk di dalamnya minat berwirausaha sehingga keberadaan lingkungan keluarga dalam pembentukan minat wirausaha seseorang menjadi sangat penting. Seseorang yang tumbuh di lingkungan bisnis secra relatif akan mempuyai kesempatan yang lebih besar untuk menjadi wirausahawan. Jiwa kewirausahaan juga bisa tumbuh dan berkembang karena pengaruh lingkungan fisik di sekitarnya. Temuan penelitian ini memberikan bukti empirik bahwa prediktor utama dari niat adalah faktor eksternal untuk melakukan niat tersebut serta mendukung temuan dari penelitian-penelitian terdahulu dalam berbagai konteks (Afifah et al, 2016; Ananta \& Oktafani, 2019. Nagel \& Suhartatik,2018). Namun hasil penelitian ini justru berlawanan dengan hasil penelitian (Tisa \& Anggadwita (2018) yang menyatakan bahwa faktor eksternal justru tidak mempengaruhi niat seseorang berwirausaha.

\section{KESIMPULAN}

Dari hasil uji statistik dapat disimpulkan bahwa sikap berpengaruh positif dan signifikan terhadap Interpreneurial Intentions, artinya semakin tinggi sikap maka semakin baik Interpreneurial Intentions, Hal ini sesuai dengan tingginya nilai skor yang mereka berikan untuk indikator tertarik dengan peluang usaha.

Norma subyektif berpengaruh positif dan signifikan terhadap Interpreneurial Intentions artinya semakin tinggi Norma Subyektif maka semakin baik Interpreneurial Intention, sebaliknya semakin kurang Norma Subyektif auditor maka semakin rendah Interpreneurial Intentions. Hal ini sesuai dengan tingginya nilai skor yang mereka berikan untuk indikator motivasi prestasi, motivasi afiliasi, motivasi kompetensi, motivasi kekuasaan.

Faktor internal berpengaruh positif dan signifikan terhadap Interpreneurial Intentions. Jadi faktor internal berpengaruh kecil terhadap Interpreneurial Intentions. Hal ini sesuai dengan tingginya nilai skor yang mereka berikan untuk indikator melakukan perencanaan untuk memulai usaha.

Faktor eksternal berpengaruh positif dan signifikan terhadap Interpreneurial Intentions. Hal ini sesuai dengan tingginya nilai skor yang mereka berikan untuk indikator pekerjaan orang tua, dukungan orang tua.

Implikasi Praktis / Teoritis

Hasil penelitian ini mendukung Theory of Planned Behavior/TPB (Ajzen, 1991) khususnya terkait Interpreneurial Intentions.

\section{Keterbasan dan Saran}

Hasil penelitian ini hanya mampu menjelaskan Interpreneurial Intentions hanya sebesar 35,8 $\%$ saja dan sisanya 64,2 \% dijelaskan variabel lain. Oleh karena itu, penelitian mendatang diharapkan menambah jumlah responden, variabel bebasnya supaya dapat menggali informasi lebih detail terkait Interpreneurial Intentions.

\section{REFERENSI}

Ajzen, Icek (1991). The Theory of Planned Behavior. Journal ofOrganizational Behavior and Human Decision Processes, Vol. 50, 179 - 211.

Afifah, Z., Pardiman \& Khalikussabir. 2016. Analisa Faktor Internal Dan Faktor Eksternal Terhadap Minat Mahasiswa Dalam Berwirausaha (Studi Pada Mahasiswa Feb Universitas Islam Malang Angkatan 2016). E - Jurnal Riset Manajemen Prodi Manajemen. 138-152

Ajzen, I., \& Fishbein, M. (1980). Understanding Attitudes and Predicting Social Behaviour. New York: Pretience Hall. 
Ananta, W. Y., \& Oktafani, F. (2019).Pengaruh Faktor Internal Individu Dan Lingkungan Eksternal Terhadap Minat Berwirausaha Mahasiswa Jurusan Bisnis Pada Universitas Di Kota Bandung Tahun 2019. e-Proceedings of Management, 6(2). 1-8

Andika, Manda \& Madjid, Iskandarsyah. 2012. Analisis Pengaruh Sikap, Norma Subjektif dan Efikasi Diri Terhadap Intensi Berwirausaha Pada Mahasiswa Fakultas Ekonomi Universitas Syiah Kuala (Studi pada Mahasiswa Fakultas Ekonomi Universitas Syiah Kula). Proceeding EcoEntrepreneurship Seminar \& Call Paper "Improving Perfomance by Improving Environment 2012.190-197

Davis, Keith \& John W., Newstorm. 1996. Perilaku Dalam Organisasi, Alih Bahasa Agus Dharma, Jakarta : Erlangga.

Dharmmesta, B.S. 1998, Teory Of Planned Behavior Dalam Penelitian Sikap, Niat dan Perilaku Konsumen, Jurnal Kelola. No. 18/VII/1998.

Drucker, Peter.F, 1999. Manajemen: Tugas, Tanggung Jawab dan Praktek, Jakarta: PT Gramedia

Hadiyati, Ernani. 2011. Kreatifitas dan Inovasi Berpengaruh Terhadap Kewirausahaan Usaha Kecil. Jurnal Manajemen dan Kewirausahaan. 13(1). 8-16.

Heidjrahman, RP. 1982, Pengantar Ekonomi Perusahaan, Yogyakarta. Penerbit BPFE UGM.

Hisrich, R.D. Peters, M.P. \& Shephred, D.A. 2008. Kewirausahaan, Edisi Tujuh. Jakarta: Salemba Empat.

Hogg, Michael A \& Vaughan Graham M. 2005. Social Psychology, 4th edition. British Library Cataloguing in Publication Data

Ifham, Akmad \& Helmi, Afin F. 2002. Hubungan Kecerdasan Emosi dengan Kewirausahaan pada Mahasiswa. Jurnal Psikologi. No 2. 89-111

Jogiyanto. 2008. Analisis dan Desain Sistem Informasi : Pendekatan Terstruktur. Teori dan Praktek Aplikasi Bisnis. Yogyakarta: Andi Offsite

Kourilsky, M. L. \& W. B. Walstad, 1998. Entrepreneurship and female youth: knowledge, attitude, gender differences, and educational practices. Journal of Business Venturing. Vol. 13 (1). 77-88.

Kurnianto, BS. \& Putra, Sulistya E, 2012, Menumbuh Kembangkan Minat Berwirausaha Bagi Para Mahasiswa Di Lingkungan Perguruan Tinggi, Prosiding Seminar \& Konferensi Nasional Manajemen Bisnis, 26 Mei 2012

Law, P., \& Hung, J. 2009. Factors influencing Hong Kong CPAs' entrepreneurship in the accounting profession. Journal of Human Resource Costing \& Accounting. 13(1), 29-45

McClelland, David C. 2009. Entrepreneur Behavior and Characteristics of Entrepreneurs.The Achieving Society.

Meredith, Geoffrey G., Nelson, Robert E, \& Neck, Philip, A. (2000). The Practice of Entrepreneurship. Geneva, International Labour Office

Mihartinah, Duwi \& Corynata, Isma. 2018. Pengaruh Sikap Terhadap Perilaku, Norma Subjektif, Dan Kontrol Perilaku Persepsian Terhadap Niat Mahasiswa Akuntansi Untuk Mengambil Sertifikasi Chartered Accountant. Jurnal Akuntansi. 8(2), 77-87

Nagel, PJF \& Suhartatik, Ani. 2018. Faktor Internal dan Eksternal Minat Berwirausaha dan Keberhasilan Usaha pada UMKM di Surabaya. Jurnal Keuangan dan Perbankan, 15(1). 5363

Rachbini, Didik J, 2001. Pembangunan Ekonomi \& Sumber Daya Manusia. Jakarta. Gramedia Widiasarana Indonesia.

Ramayah, T., \& Harun, Z, 2005. Entrepreneurial Intention Among the Studen of Universiti Sains Malaysia (USM). International Journal of Management and Entrepreneurship, 1. 8-20.

Shaw, M.E., \& Costanzo, P.R. 1970. Theories of Social Psychology. New York: Mc Graw Hill Co.

Siagian, Sondang. P. (2016). Manajemen Sumber Daya Manusia. Cetakan ke-24. Jakarta: Bumi Aksara

Sumadi, AR \& Sulistyawati, IE. 2017. Pengaruh Sikap, Motivasi, Dan Lingkungan Terhadap Niat Berwirausaha. E-Jurnal Manajemen Unud, 6(2), 2017. 1007-1029 
Tisa, Andita \& Anggadwita, Grisna. 2018. Pengaruh Faktor Internal Dan Faktor Eksternal Terhadap Minat Berwirausaha Pada Women Entrepreneur Pemilik Usaha Fashion Di Kota Bandung. e-Proceeding of Management. 5(2). 1860-1866

Tjahjono, H.K \& Ardi, H. 2008. Kajian Niat Mahasiswa Manajemen Universitas Muhammadiyah Yogyakarta Untuk Menjadi Wirausaha. Jurnal Manajemen dan Bisnis. 16(1). 46-63

Widhiandono, H, Miftahuddin MA \& Darmawan A. 2016. Pengaruh Faktor Internal, Faktor Eksternal dan Faktor Pendidikan terhadap Intensi Kewiausahaan Alumni Mahasiswa. Proceeding Seminar Nasional Ekonomi dan Bisnis dan Call For Paper. FEB UMSIDA.

Wijaya, Tony, 2008. Kajian Model Empiris Berwirausaha UKM DIY dan Jawa Tengah. Jurnal Manajemen dan Kewirausahaan.10(2). 93-104

Zhao X, Yang P, Gai R, Mei L, Wang X, Xu L. 2013. Determinants of health careseeking delay among tuberculosis patients in Shandong Province, China. European Journal of Public Health.24(5):757-761

Yaspita, H. (2018). Pengaruh Faktor Internal Dan Eksternal Terhadap Minat Berwirausaha Mahasiswa Konsentrasi Kewirausahaan Di Sekolah Tinggi Ilmu Ekonomi Indragiri (STIEI) Rengat. Jurnal Manajemen dan Bisnis, 7(4), 123-136.

\section{Profil Penulis}

Dian Triyani, SE, MM adalah dosen Manajemen Sumber Daya Manusia di Fakultas Ekonomi Universitas Semarang. Beliau pernah diberi penugasan sebagai Sekretaris Program Studi D3 Manajemen Perusahaan pada dua periode yang berbeda. Beliau ini masih mengemban tugas sebagai pengelola Jurnal Ilmiah Solusi di tingkat Fakultas Ekonomi Universitas Semarang. Pada bidang pengajaran, mata kuliah yang menjadi konsentrasi beliau adalah Manajemen Sumber Daya Manusia. Beliau aktif melakukan kegiatan dibidang penelitian, baik pendanaan mandiri maupun di danai oleh LPPM Universitas Semarang. Pada bidang publikasi karya ilmiah, beliau aktif mengikuti seminar dan konferensi di tingkat nasional untuk melakukan diseminasi hasil penelitian yang dimuat di prosiding. Alamat email beliau adalah diantriyaniyanata@gmail.com

Dr. Ardiani Ika Sulistyawati, SE, MM, Akt, CA, CPA adalah dosen Akuntansi di Fakultas Ekonomi Universitas Semarang yang saat ini menjabat sebagai Ketua Badan Penjaminan Mutu. Sebelumnya beliau pernah menjabat sebagai Sekretaris Jurusan merangkap Sekretaris Program Studi S1 Akuntansi. Penugasan berikutnya adalah sebagai Ketua Jurusan merangkap Ketua Program Studi S1 Akuntansi. Pada bidang pengajaran, konsetrasi mata kuliah yang biasa diampu adalah Pengantar Akuntansi, Akuntansi Biaya, Akuntansi Manajemen dan Metodologi Penelitian. Beliau pernah cukup lama (kurang lebih10 tahun) mendapat tugas sebagai pengelola Jurnal Ilmiah di tingkat Fakultas Ekonomi Universitas Semarang. Saat ini, beliau masih menjadi reviewer artikel pada beberapa jurnal nasional. Pada bidang penelitian, beberapa tahun lalu beliau mendapatkan hibah penelitian DRPM. Selain itu beberapa penelitian didanai oleh LPPM USM dan cukup banyak pula penelitian yang didanai mandiri. Saat ini beliau masih tercatat sebagai Reviewer Nasional Bersertifikat LLDIKTI.

Alamat email aktif beliau adalah ardiani@usm.ac.id

Edy Mulyantomo, SE, MM adalah dosen senior konsentrasi Manajemen Pemasaran di Fakultas Ekonomi Universitas Semarang. Beliau pernah menjabat sebagai Kepala Pusat Pusat Komputer dan pernah pula menjabat Sekretaris Jurusan merangkap Sekretaris Program Studi S1 Manajemen. Bidang pengajaran beliau adalah pada mata kuliah Komunikasi Bisnis, Negosiasi Bisnis, Pengantar Manajemen dan Sistem Informasi Manajemen. Beliau aktif melakukan kegiatan Pengabdian kepada Masyarakat dengan tema Marketing dan Pentingnya Pembukuan Usaha bagi khayalak sasaran. Alamat aktif email beliau adalah edymul@usm.ac.id. 